\title{
Influence of Dry Methane Reactions on the Cell Output Characteristics of Solid Oxide Fuel Cells
}

\author{
Hongxin You',2, Bin Qu1 ${ }^{1}$, Guoqing Guan², Abudula Abuliti² \\ ${ }^{1}$ Chemical Environment and Life Science Division, Dalian University of Technology, Dalian, China \\ ${ }^{2}$ North Japan Research Institute for Sustainable Energy, Hirosaki University, Aomori, Japan \\ Email:youhx@sina.com
}

Received 19 January 2015; accepted 24 February 2015; published 28 February 2015

Copyright (C) 2015 by authors and Scientific Research Publishing Inc.

This work is licensed under the Creative Commons Attribution International License (CC BY). http://creativecommons.org/licenses/by/4.0/

c) (i) Open Access

\section{Abstract}

In order to study the influence of dry methane concentration on outputs in solid oxide fuel cells (SOFCs), the output performance was obtained for dry methane of different concentrations on a $\mathrm{Ni}$-ScSZ anode in solid oxide fuel cells, and the anode exhaust gas was measured by on-line chromatography. The underlying causes of the output performance change were analyzed from the anode reactions by summarizing the anode exhaust gas regular pattern for different reactions, and analyzing the electrochemical reaction kinetics of methane with oxygen ion. As the oxygen ion concentration at the anode three-phase boundary proportionally increased with current density, the following reactions occurred for different dry methane concentrations in sequence $\mathrm{CH}_{4}+\mathrm{O}^{2-} \rightarrow$ $\mathrm{CO}+2 \mathrm{H}_{2}+2 \mathrm{e}^{-}, \mathrm{CH}_{4}+2 \mathrm{O}^{2-} \rightarrow \mathrm{CO}+\mathrm{H}_{2} \mathrm{O}+\mathrm{H}_{2}+4 \mathrm{e}^{-}, \mathrm{CH}_{4}+3 \mathrm{O}^{2-} \rightarrow \mathrm{CO}+2 \mathrm{H}_{2} \mathrm{O}+6 \mathrm{e}^{-}, \mathrm{CH}_{4}+4 \mathrm{O}^{2-} \rightarrow \mathrm{CO}_{2}+$ $2 \mathrm{H}_{2} \mathrm{O}+8 \mathrm{e}^{-}$. With various concentrations of methane at a low current, the outlet methane continuously reduced with the increase of the current density. Meanwhile, $\mathrm{CO}$ and $\mathrm{H}_{2}$ exhaust gas increased with increasing current density for low concentration of methane. With methane concentrations at $3.85 \%$ and $5.66 \%$, the cell output voltage dropped rapidly. For concentrations of $29.7 \%$ and $3.85 \%$, the anode exhaust residual methane changed irregularly with current density and this phenomenon was associated with the dry methane that reacted on anode of the cell. The transformation of reactions, the water produced in the electrochemical reactions and the polarization in response to the change of reactions maybe induced the output voltage and power density reducing as low concentrations of dry methane were used.

\section{Keywords}

Solid Oxide Fuel Cell, Reaction, Methane, Output Performance 


\section{Introduction}

Dry methane and oxygen ions that are derived from cathodes can produce a multitude of chemical reactions in a solid oxide fuel cell anode. The reactions of methane on the anode are also the oxidation reaction. The partial oxidation reaction of methane was founded by K. Kendall [1] under open circuit conditions, using the Nernst equation and by analyzing the open circuit voltage of this system. The study of anode reactions and electronic analysis of oxygen ions from anode exhaust gas by Abuliti [2] found that dry methane occurs from the partial oxidation reaction of $\mathrm{CH}_{4}+\mathrm{O}^{2-} \rightarrow \mathrm{CO}+2 \mathrm{H}_{2}+2 \mathrm{e}^{-}$when current density on the Ni-YSZ anode is low by using $4.2 \%$ dry methane. However, complete oxidation reactions have occurred with $4.2 \%$ high current density dry methane. The partial oxidation reaction of dry methane only occurred at the concentration of $29 \%$ dry methane under different current densities [3].

Some research found an effective measure for improving power generation performance by using a material with higher electric conductivity. The conductivity of $8 \%$ yttria-stabilized zirconia (YSZ) is $0.1 \mathrm{~S} \cdot \mathrm{cm}^{-1}$, which greatly influences cell performance. In order to avoid this influence on cell performance, it is necessary to adopt a new material with high electric conductivity in place of YSZ, such as scandia-stabilized zirconia (ScSZ), which has a conductivity of 0.3 [4].

On the Ni-ScSZ anode, 3\% $\mathrm{H}_{2} \mathrm{O}-\mathrm{CH}_{4}$ can be used in SOFC as a fuel [5]. Compared with the Ni-YSZ anode, the Ni-ScSZ anode exhibited lower overpotential and excellent durability. Gunji [6] et al. studied the depositional behavior of carbon on the Ni-ScSZ anode with $97 \% \mathrm{CH}_{4}+3 \% \mathrm{H}_{2} \mathrm{O}$ as the fuel source. The cell voltage was reduced and unstable at $1073 \mathrm{~K}$. However, the cell performance began to increase in the initial $70 \mathrm{~h}$ at 1173 $\mathrm{K}$ and later became stable.

You [7] carried out experiments using low concentrations of dry methane on the Ni-YSZ and Ni-ScSZ anode, respectively, and measured the components of the anode exhaust gas and analyzed the produced characteristics of the anode exhaust gas. Combined with methane and oxygen ions reaction kinetics, and with the current density traveling from low to high, the methane occurred following reactions on $\mathrm{Ni}$ based anodes in the following sequence: partial oxidation reaction, $\mathrm{CH}_{4}+2 \mathrm{O}^{2-} \rightarrow \mathrm{CO}+\mathrm{H}_{2} \mathrm{O}+\mathrm{H}_{2}+4 \mathrm{e}^{-}, \mathrm{CH}_{4}+3 \mathrm{O}^{2-} \rightarrow \mathrm{CO}+2 \mathrm{H}_{2} \mathrm{O}+6 \mathrm{e}^{-}$, and complete oxidation reaction. When the reaction changed, the output voltage of $\mathrm{Ni}-\mathrm{ScSZ}$ anode cell was reduced.

Methane on the solid oxide fuel cell anode occurs with the partial oxidation reaction that resulted when the 1 mol methane reaction released 2 mol electron, the reaction of $\mathrm{CH}_{4}+\mathrm{O}^{2-} \rightarrow \mathrm{CO}+\mathrm{H}_{2}+2 \mathrm{e}^{-}$occurred. Methane on the SOFC anode occurs following the complete oxidation reaction [8] [9] that 1 mol methane reaction released 8 mol electron, as the reaction of $\mathrm{CH}_{4}+4 \mathrm{O}^{2-} \rightarrow \mathrm{CO}_{2}+2 \mathrm{H}_{2} \mathrm{O}+8 \mathrm{e}^{-}$occurred. The partial oxidation reaction and complete oxidation reaction can be carried out, not only in the nickel based catalyst, but also in cerium based [8] and lanthanum chromite based catalysts [10]. At first view of the above two reactions, in order to use methane as the cell fuel in SOFC and make SOFC produce more power, a complete oxidation reaction with methane as a fuel source should be accomplished on the SOFC anode for obtaining a high power generation performance.

To research methane reaction models and their influence on cell output characteristics in SOFC, experiments were carried out using different flows of dry methane on an Ni-ScSZ anode. Through researching the cell power performance and characteristics of the anode exhaust gas, we can analyze the characteristics of anodic oxidation reactions so that dry methane service can be used in SOFC reasonably.

\section{Experiment}

\subsection{Single Cell Preparation}

The solid electrolyte YSZ (8 mol\% $\mathrm{Y}_{2} \mathrm{O}_{3}$ ) substrate used in the experiments was purchased from Japan (Tosoh). The diameter and thickness of the YSZ substrate were $20.0 \mathrm{~mm}$ and $1.0 \mathrm{~mm}$, respectively. The anode material used in the experiment was Ni-ScSZ, and was made by mixing and grinding $\mathrm{NiO}$ and ScSZ with a mass ratio of 3:2. $50 \%$ of binder and $10 \%$ of pore forming agent were added and grinded. An anode slurry grinded well wascoated on one side of the electrolyte substrate, then the electrolyte substrate was put into the high temperature heating furnace. The electrolyte substrate was calcined at $1673 \mathrm{~K}$ for 2 hours and was slowly cooled. The anode area of the fuel cell was $0.78 \mathrm{~cm}^{2} . \mathrm{La}_{0.85} \mathrm{Sr}_{0.15} \mathrm{MnO}_{3-\delta}$ (LSM) was coated on the side opposite of the electrolyte substrate and used as the cathode material. The method used to coat the cathode material was the same as the anodic method, except the cathode calcining temperature was $1473 \mathrm{~K}$. 


\subsection{Cell Power Test}

The method of cell clamping installation was the same as that has been previously described in the literature [11]. During the cell test, the methane that passed into the anode was always diluted to the required concentration of $50 \mathrm{ml} \cdot \mathrm{min}^{-1}$ argon. Oxygen with a purity of $99.9 \%$ was passed into the cathode and its flux was 50 $\mathrm{ml} \cdot \mathrm{min}^{-1}$. The test was started after the open circuit voltage was stable. Agilent GC 7890 A chromatography online was used to detect the anode exhaust gas in the experiment. After completing the experiment of one concentration of methane, argon gas was used to replace the anode chamber and measure the anode exhaust gas using chromatography until the anode exhaust gas was without fuel gas.

In order to assess the performance of the researched cell, ac impedance was used to test cell performance in open circuit. The AC impedance measurement device used in the test was Solartron 1255B + Solartron SI 1287 A. During open circuit test, an alternating current of $0.001 \mathrm{~A}$ was set and the frequency range was from $1,000,000 \mathrm{~Hz}$ to $0.1 \mathrm{~Hz}$.

\section{Experimental Results and Discussion}

\subsection{Cell Power Performance}

Figure 1 depicts the power generation performance curve of Ni-ScSZ anode cellsat $1273 \mathrm{~K}$, with $29.7 \% \mathrm{CH}_{4}+$ 70.3\% Ar, 10.7\% $\mathrm{CH}_{4}+89.3 \% \mathrm{Ar}, 7.41 \% \mathrm{CH}_{4}+92.59 \% \mathrm{Ar}, 5.66 \% \mathrm{CH}_{4}+94.34 \% \mathrm{Ar}$ and 3.85\% $\mathrm{CH}_{4}+96.15 \%$ Ar as fuel, respectively. Open circuit voltage of the cells was higher than $1.43 \mathrm{~V}$, which illustrates the quality seal of the cells. Figure 2 shows the cell impedance spectra when open for different methane concentrations. For four dry methane flows from high to low, ohm impedances were $1.047 \mathrm{ohm}, 0.9882 \mathrm{ohm}, 1.062 \mathrm{ohm}$ and 1.215 ohm, respectively. The half-arcs of the figure after fitting and intersecting in $\mathrm{X}$ axis showed that activation impedances were $0.954 \mathrm{ohm}, 0.818 \mathrm{ohm}, 0.622 \mathrm{ohm}$ and $0.637 \mathrm{ohm}$. Activation impedance and ohm impedance are very small, and the impedances of each cell under the open circuit showed little difference, suggesting the cell manufacturing process was essentially stable.

The maximum power densities of the four cells were $0.275 \mathrm{~W} \cdot \mathrm{cm}^{-2}, 0.234 \mathrm{~W} \cdot \mathrm{cm}^{-2}, 0.229 \mathrm{~W} \cdot \mathrm{cm}^{-2}$ and 0.192 $\mathrm{W} \cdot \mathrm{cm}^{-2}$, respectively. This confirms that the cells had good power performance at high methane concentration. For a cell methane concentration of $3.85 \%$, the output power was low. However, when the cell in the current density was greater than $0.192 \mathrm{~A} \cdot \mathrm{cm}^{-2}$, the output voltage dropped rapidly. A methane concentration of $5.66 \%$ also created a similar phenomenon when the cell in the current density was greater than $0.256 \mathrm{~A} \cdot \mathrm{cm}^{-2}$. As current density increased, the output voltage declined at a fast rate. During the cell test, a cell methane concentration of $7.41 \%$ of the cell appeared in the experiment (Figure 3). As the current density approached 0.256

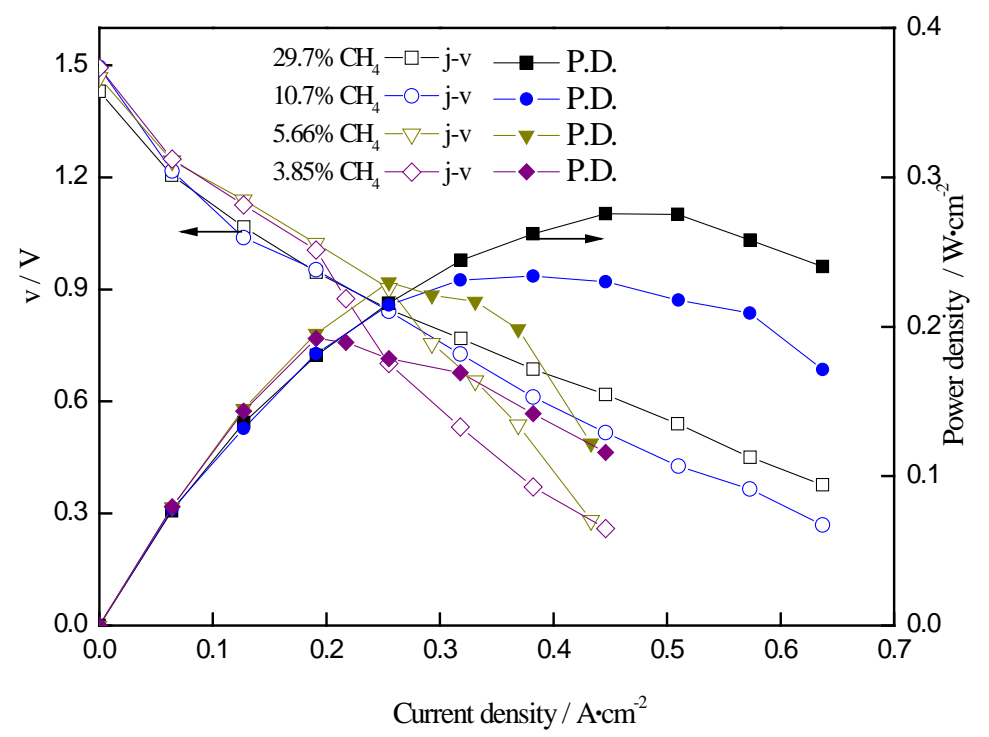

Figure 1. J-V characteristics and power density with different methane concentrations at $1273 \mathrm{~K}$. 


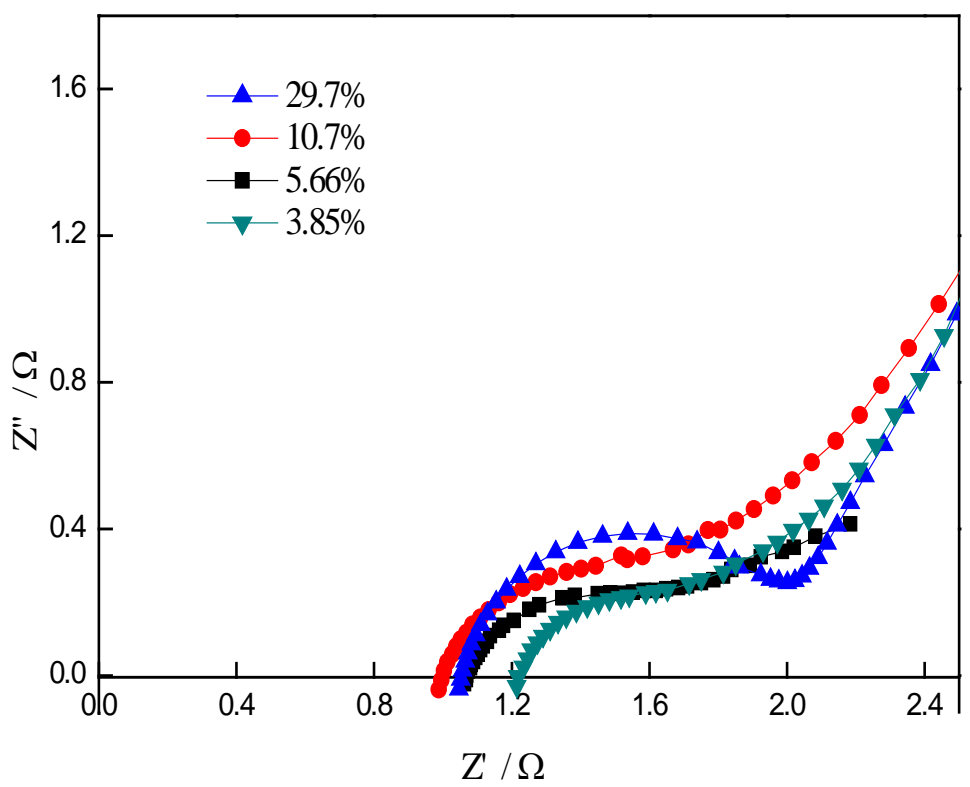

Figure 2. Impedance spectra at open for the different methane concentrations at $1273 \mathrm{~K}$.

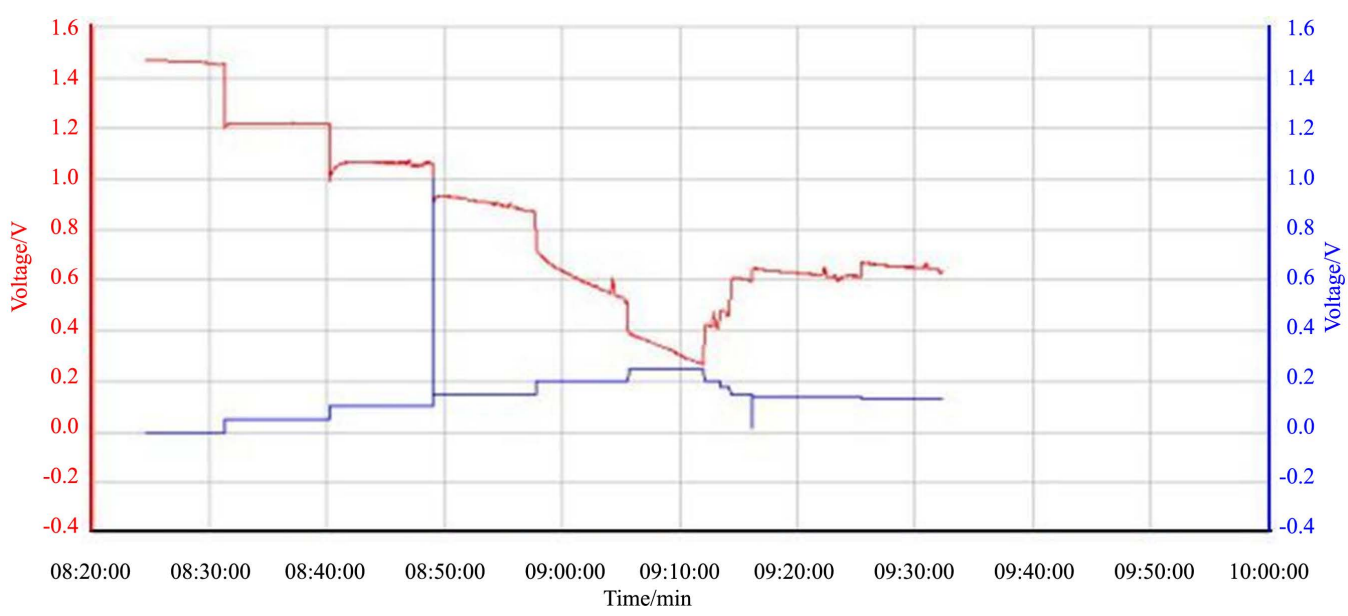

Figure 3. The process of power generation of the cell with $7.41 \% \mathrm{CH}_{4}$.

$\mathrm{A} \cdot \mathrm{cm}^{-2}$, the voltage declined continuously through time, which prevented further measurements from being taken. The cell concentrations of $5.66 \%$ and $3.85 \%$ also showed similar problems in the test process of power generation performance, but did not hinder measurements from being taken.

\subsection{The Anode Exhaust Gas}

The anode exhaust gas pass on important information in determining the cell reaction. Figure 4 shows the exhaust gas composition with different concentrations of methane after cell anode reaction and carbon precipitation after methane pyrolysis in the anode chamber at $1273 \mathrm{~K}$ on the Ni-ScSZ anode. The water of reaction product was calculated in accordance with the method of the oxygen balance [12]. Figure 4 shows a correlative relationship between releasing $\mathrm{H}_{2}$ and $\mathrm{CO}$ and the relationship is represented with 0.5 times of $\mathrm{H}_{2}$.

With various concentrations of methane at a low current, the outlet methane continuously reduced with the increase of the current density (Figure 4). Meanwhile, $\mathrm{CO}$ and $\mathrm{H}_{2}$ exhaust gas increased with increasing current density. 


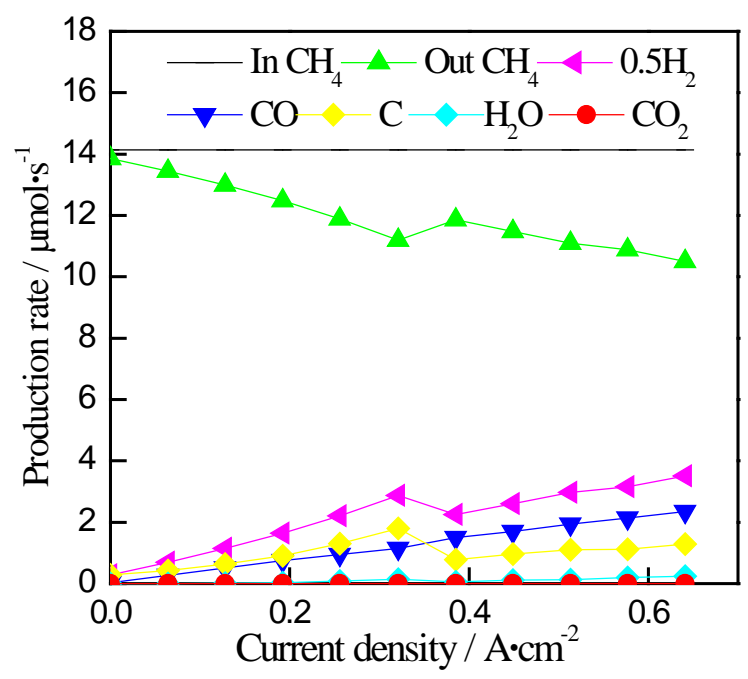

(a)

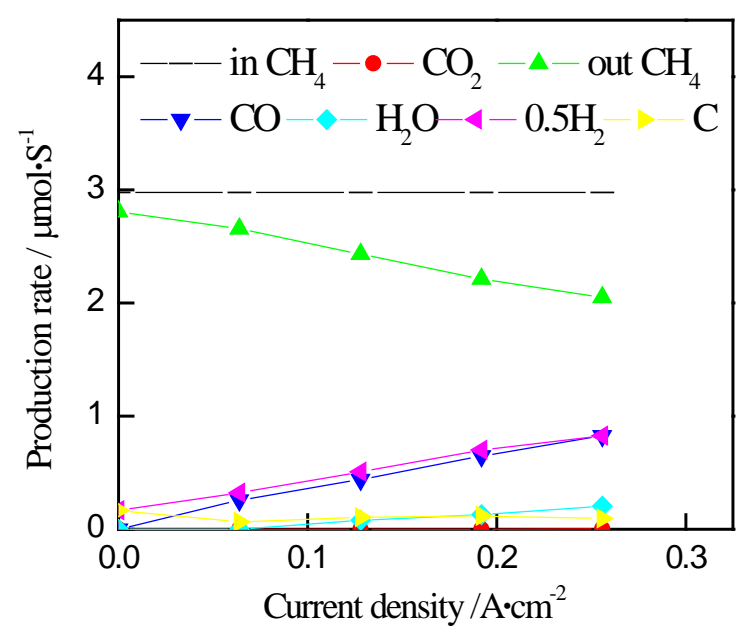

(c)

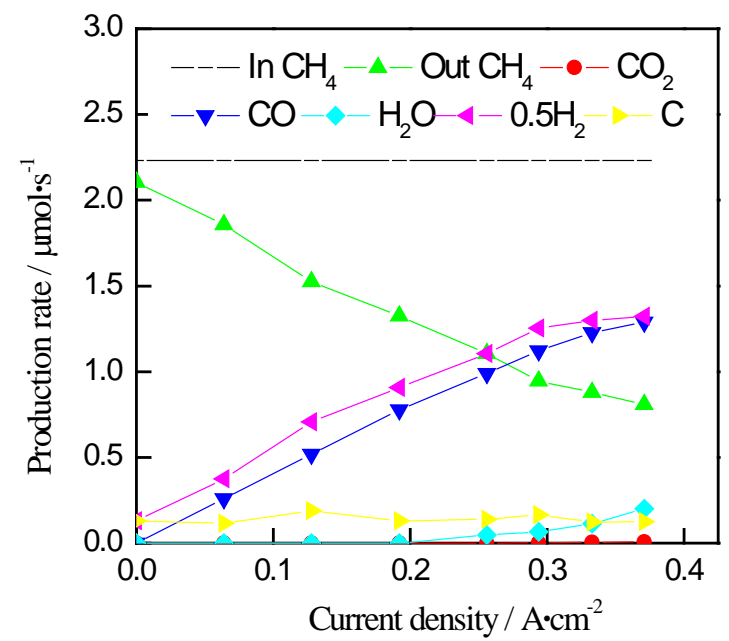

(b)

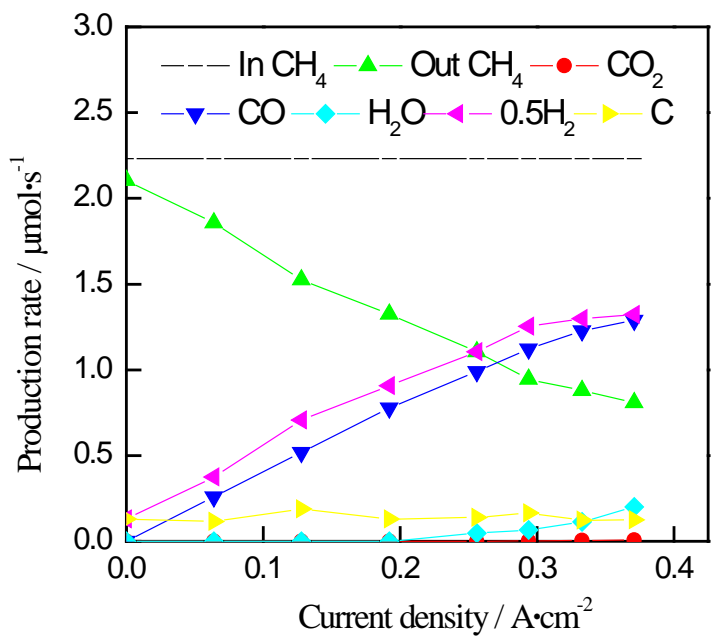

(d)

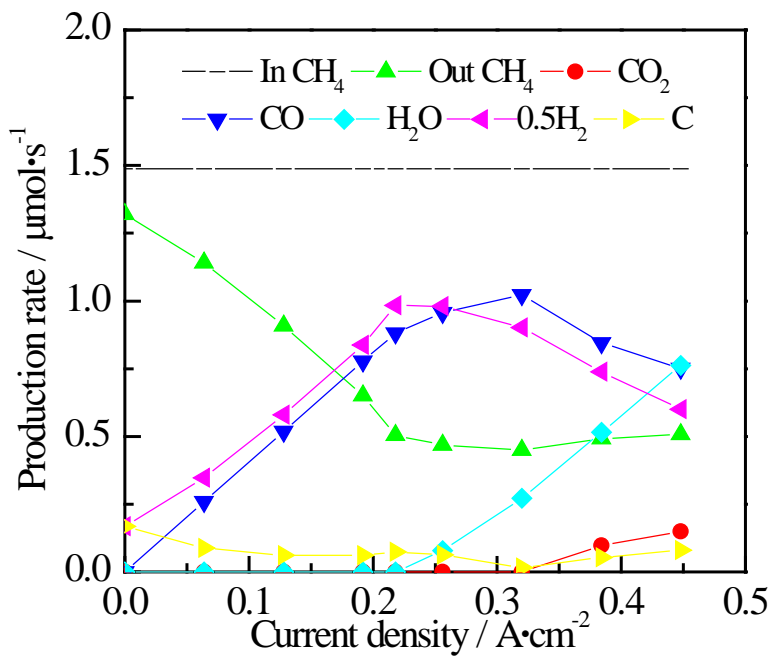

(d)

Figure 4. The production rates for different methane flux on the cell with Ni-ScSZ anode at $1273 \mathrm{~K}$ (a) $29.7 \% \mathrm{CH}_{4}$; (b) $10.7 \% \mathrm{CH}_{4}$; (c) $7.41 \% \mathrm{CH}_{4}$; (d) $5.66 \% \mathrm{CH}_{4}$; (e) $3.85 \% \mathrm{CH}_{4}$. 
For the $29.7 \%$ dry methane at a current density between $0.321 \mathrm{~A} \cdot \mathrm{cm}^{-2}$ and $0.386 \mathrm{~A} \cdot \mathrm{cm}^{-2}$, there was sudden change in the outlet methane (Figure 4(a)). The outlet methane firstly increased suddenly, then a subsequent decrease. However, corresponding $\mathrm{H}_{2}$ and $\mathrm{H}_{2} \mathrm{O}$ brought about a contrary change with the outlet methane, and $\mathrm{H}_{2}$ and $\mathrm{H}_{2} \mathrm{O}$ firstly decreased suddenly, and then increased continuously. But CO had no the trend following the increase of current density.

For the $10.7 \%$ dry methane, the outlet methane continuously decreased with the increase of the current density. The $\mathrm{CO}$ and $\mathrm{H}_{2}$ in the exhaust gas increased with the increase of the current density when the current density was at $0.321 \mathrm{~A} \cdot \mathrm{cm}^{-2}$ and $0.256 \mathrm{~A} \cdot \mathrm{cm}^{-2}$, after the calculation the exhaust gas has a certain amount of water (Figure 4(b)). When the current density was at $0.449 \mathrm{~A} \cdot \mathrm{cm}^{-2}$, trace amounts of $\mathrm{CO}_{2}$ were measured in the exhaust gas.

For the $5.66 \%$ dry methane, the outlet methane also continuously decreased with the increase of the current density, and $\mathrm{CO}$ and $\mathrm{H}_{2}$ inexhaust gas increased with the increase of the current density (Figure 4(d)). $\mathrm{CO}_{2}$ was found in the exhaust gas when the current density was $0.385 \mathrm{~A} \cdot \mathrm{cm}^{-2}$. The exhaust gas began to produce water at the current density of $0.256 \mathrm{~A} \cdot \mathrm{cm}^{-2}$.

For the $3.85 \%$ dry methane, increasing current density corresponded to rapidly decreasing outlet methane (Figure 4(e)). $\mathrm{CO}$ and $\mathrm{H}_{2}$ rapidly increased at first. After both reach a maximum production rate, the $\mathrm{H}_{2}$ decreases at a large rate. The CO remained stable at a high level, until it began to gradually decrease. After the outlet methane was reduced to a lower level, little change was recorded. When the current density was low, $\mathrm{CO}_{2}$ and $\mathrm{H}_{2} \mathrm{O}$ did not appear in exhaust gas. When the $\mathrm{CO}$ and $\mathrm{H}_{2}$ increased rapidly, $\mathrm{H}_{2} \mathrm{O}$ first appeared in exhaust gas, then $\mathrm{CO}_{2}$ appeared. As the current density increased, the carbon precipitation reduced gradually. $\mathrm{H}_{2} \mathrm{O}$ began to be produced in the current at a density of $0.385 \mathrm{~A} \cdot \mathrm{cm}^{-2}$, and $\mathrm{CO}_{2}$ was measured in the current at a density of $0.384 \mathrm{~A} \cdot \mathrm{cm}^{-2}$.

For the $29.7 \%$ dry methane, irregularity of change in the outlet methane was similar to test results using a $14.8 \%$ concentration of dry methane on $\mathrm{Ni}_{0.5} \mathrm{Cu}_{0.5}$-CGO anode [13] [14]. For $3.85 \%$ of dry methane the outlet methane also changed irregularly, suggesting the necessity of careful study in the future.

\subsection{Anode Reaction}

With methane concentrations at 3.85\% and 5.66\%, the cell output voltage dropped rapidly. For concentrations of $29.7 \%$ and $3.85 \%$, the anode exhaust residual methane changed irregularly with the current density and this phenomenon was associated with the dry methane that reacted on anode of the cell.

For internal reforming and dry reforming of methane, the reaction residence time was a few seconds [15]. In the literature [16]-[18], according to the reaction thermodynamics, the multiple reaction steps of the activation energy were given describing methane and oxygen on the Ni-based anode. Drawing reaction route diagrams is shown in Figure 5. The reaction activation energy and numerical value marked on the line in the figure is the activation energy of the step, the unit of which is $\mathrm{KJ} \cdot \mathrm{mol}^{-1}$.

Under specific reaction conditions, the main products of the reaction must be from a relatively stable process with the lowest activation energy. The dry methane reaction produced $\mathrm{C}, \mathrm{H}_{2}, \mathrm{CO}, \mathrm{H}_{2} \mathrm{O}$ and $\mathrm{CO}_{2}$ in order along a continuous variation of the current density. The activation energy for the precipitation of $1 \mathrm{molC}(\Sigma \mathrm{Ea})$ was $273.6 \mathrm{KJ} \cdot \mathrm{mol}^{-1}$, and the activation energy of $1 \mathrm{~mol} \mathrm{H}_{2}(\Sigma \mathrm{Ea})$ by generating was $245.8 \mathrm{KJ} \cdot \mathrm{mol}^{-1}$, $361.7 \mathrm{KJ} \cdot \mathrm{mol}^{-1}$ and $389.9 \mathrm{KJ} \cdot \mathrm{mol}^{-1}$ through different routes. Meanwhile, the activation energy of $1 \mathrm{~mol} \mathrm{H}_{2} \mathrm{O}(\Sigma \mathrm{Ea})$ by generating was $361.0 \mathrm{KJ} \cdot \mathrm{mol}^{-1}$ and $505.1 \mathrm{KJ} \cdot \mathrm{mol}^{-1}$ through different routes, the activation energy of $1 \mathrm{~mol} \mathrm{CO}(\Sigma \mathrm{Ea})$ was $414.7 \mathrm{KJ} \cdot \mathrm{mol}^{-1}$, and the activation energy of $1 \mathrm{~mol} \mathrm{CO}_{2}(\Sigma \mathrm{Ea})$ was $574.0 \mathrm{KJ} \cdot \mathrm{mol}^{-1}$. Although the total activation energy forming water $\left(\Sigma \mathrm{Ea}_{(\mathrm{H} 2 \mathrm{O})}=361.0 \mathrm{KJ} \cdot \mathrm{mol}^{-1}\right.$ and $\left.\Sigma \mathrm{Ea}_{(\mathrm{H} 2 \mathrm{O})}=505.1 \mathrm{KJ} \cdot \mathrm{mol}^{-1}\right)$ was less than total activation energy forming $\mathrm{CO}\left(\Sigma \mathrm{Ea}_{(\mathrm{CO})}=414.7 \mathrm{KJ} \cdot \mathrm{mol}^{-1}\right)$, the reaction was working towards forming $\mathrm{CO}$. In the process, the reaction was carried out according to the minimum activation energy, so the activation energy of forming $\mathrm{CH}(\mathrm{s})$, that was $97.1 \mathrm{KJ} \cdot \mathrm{mol}^{-1}$, was less than $97.9 \mathrm{KJ} \cdot \mathrm{mol}^{-1}$ of forming $\mathrm{OH}$ (s). According to the principle of minimum activation energy, with the increase of the current density, corresponding $\mathrm{O}_{2}$ increases and the reaction of generating $\mathrm{CO}$ and $\mathrm{H}_{2}$ should occur after generating $\mathrm{C}$ by pyrolysis of methane. Then the reactiono ccurs with the reaction of generating $\mathrm{CO}, \mathrm{H}_{2}$ and $\mathrm{H}_{2} \mathrm{O}$, and finally, the reaction of forming $\mathrm{CO}_{2}$.

Combined with exhaust gas measurement results after the anode reaction with different concentrations of dry methane as fuel in Figure 4, when the anode exhaust gas contained $\mathrm{CO}$ and $\mathrm{H}_{2}$, the cell anode should occur with the reaction of $\mathrm{CH}_{4}+\mathrm{O}^{2-} \rightarrow \mathrm{CO}+\mathrm{H}_{2}+2 \mathrm{e}^{-}$. When the anode exhaust gas contained $\mathrm{CO}, \mathrm{H}_{2}$ and $\mathrm{H}_{2} \mathrm{O}$, the cell anode should occur with the reaction of $\mathrm{CH}_{4}+2 \mathrm{O}^{2-} \rightarrow \mathrm{CO}+\mathrm{H}_{2}+\mathrm{H}_{2} \mathrm{O}+4 \mathrm{e}^{-}$. When the anode exhaust gas con- 


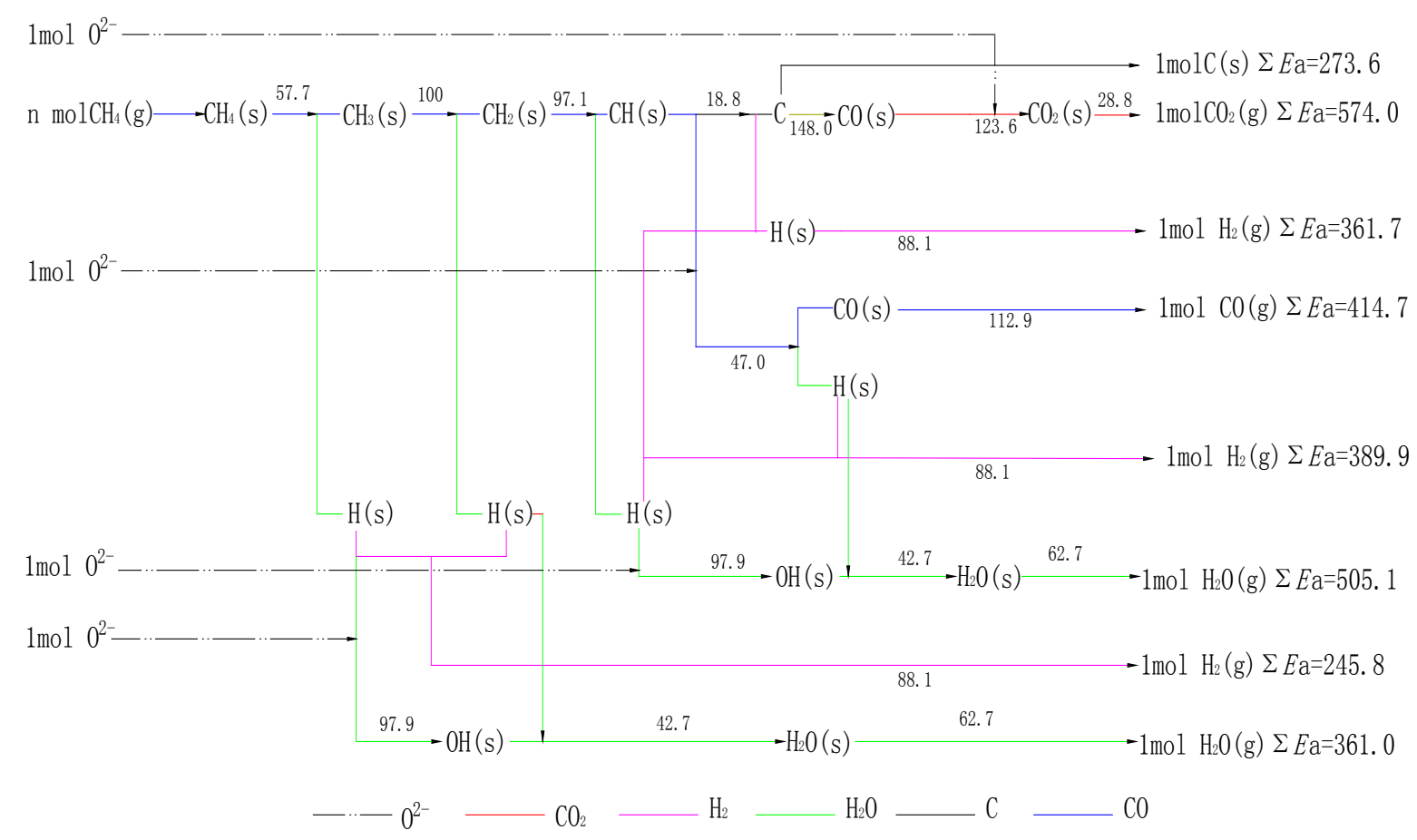

Figure 5. The reactions routes of methane at the Ni base anode.

tained $\mathrm{CO}$ and $\mathrm{H}_{2} \mathrm{O}$, the cell anode should occur with the reaction of $\mathrm{CH}_{4}+3 \mathrm{O}^{2-} \rightarrow \mathrm{CO}+2 \mathrm{H}_{2} \mathrm{O}+6 \mathrm{e}^{-}$. These reactions were reflected in Figure 4(d). When the current density moved from $0.256 \mathrm{~A} \cdot \mathrm{cm}^{-2}$ to $0.32 \mathrm{~A} \cdot \mathrm{cm}^{-2}$, the CO flux increased $0.066 \mu \mathrm{mol} \cdot \mathrm{s}^{-1}$, while the increment of $\mathrm{H}_{2} \mathrm{O}$ was $0.273 \mu \mathrm{mol} \cdot \mathrm{s}^{-1}$. With the increase of the current density, the production of water increased, indicating that it occurred from the reaction of $\mathrm{CH}_{4}+3 \mathrm{O}^{2-} \rightarrow$ $\mathrm{CO}+2 \mathrm{H}_{2} \mathrm{O}+6 \mathrm{e}^{-}$. When $\mathrm{CO}_{2}$ was contained in the exhaust gas, it showed that the dry methane completed the oxidation reaction in the anode of cell.

Under ideal conditions, $1 \mathrm{~mol}$ of methane occurring at partial oxidation reaction requires $1 \mathrm{molof} \mathrm{O}^{2-}$ and $1 \mathrm{~mol}$ of methane requires $2 \mathrm{~mol} \mathrm{O}^{2-}$ in order for the reaction $\mathrm{CH}_{4}+2 \mathrm{O}^{2-} \rightarrow \mathrm{CO}+\mathrm{H}_{2}+\mathrm{H}_{2} \mathrm{O}+4 \mathrm{e}^{-}$to occur, per unit time. 1 mol methane required $3 \mathrm{~mol} \mathrm{O} \mathrm{O}^{2-}$ to occur the reaction of $\mathrm{CH}_{4}+3 \mathrm{O}^{2-} \rightarrow \mathrm{CO}+2 \mathrm{H}_{2} \mathrm{O}+6 \mathrm{e}^{-}$while $1 \mathrm{~mol}$ methane required $4 \mathrm{~mol} \mathrm{\textrm {O } ^ { 2 - }}$ to occur complete oxidation reaction. In the case of the low flow rate of methane, the above reactions occur in sequence with the increase of the current density.

When the flow of methane was small and remained unchanged, if the current density of the cell increased so as to increase $\mathrm{O}^{2-}$ in the process, and if the current density was low, namely less $\mathrm{O}^{2-}$, the partial oxidation reaction of methane still followed. If the $\mathrm{O}^{2-}$ continuously increased, the subsequent reaction of consuming more oxygen negative ions was carried out. If the methane flowed at a medium rate, the methane was produced through a partial oxidation reaction and the reaction of consumed $2 \mathrm{~mol} \mathrm{O}^{2-}$ or $3 \mathrm{~mol} \mathrm{O}^{2-}$. The methane only occurred from partial oxidation reaction at a high flow of methane.

In the Figure 4(a), for the $29.7 \%$ dry methane, there was a linear increase of CO corresponding to an increase in current density. When the current density was between $0.321 \mathrm{~A} \cdot \mathrm{cm}^{-2}$ and $0.386 \mathrm{~A} \cdot \mathrm{cm}^{-2}$, the outlet methane had a mutation and the phenomenon was associated with anode unevenness and anode reaction. Anode reactions occurred in the three-phase interface that consisted of a catalyst, an electrolyte and the fuel gas. Uneven threephase interface caused the enrichment of the reaction medium in the anode. Once the enrichment reached a certain extent, the anode reaction type may be changed. After the current density reached $0.321 \mathrm{~A} \cdot \mathrm{cm}^{-2}$, methane content increased slightly at the anode outlet because methane content was associated with a large number of methane pyrolysis products on the anode, including $\mathrm{CH}$ in the adsorption state and partial carbon. Part of the oxygen negative ions that were associated with the cathode were used to oxidize the product $\mathrm{CH}$ by methane cracking, which had existed on the three-phase interface of the anode. They were produced by the reaction that formed $\mathrm{CO}$, rather than by the oxidization of a new methane cracking products directly. The reaction slightly in- 
creased the methane content of the anode while the methane conversion rate reduced. This process reduced the hydrogen produced by methane cracking. Therefore, when the current density was greater than $0.321 \mathrm{~A} \cdot \mathrm{cm}^{-2}$, the relative production of hydrogen in the $\mathrm{CO}$ production rate decreased.

When the current density for the low $3.85 \%$ concentration of dry methane was greater than $0.218 \mathrm{~A} \cdot \mathrm{cm}^{-2}$, the $\mathrm{CH}_{4}$ flux in the outlet exhaust gas changed slowly between $0.65 \mu \mathrm{mol} \cdot \mathrm{s}^{-1}$ and $0.45 \mu \mathrm{mol} \cdot \mathrm{s}^{-1}$ (Figure 4 (d)). When the $\mathrm{H}_{2}$ was reduced in the exhaust gas of the anode, there was a proportional increase in the water. As the $\mathrm{CO}_{2}$ in the exhaust gas was produced and began to increase, the $\mathrm{CO}$ decreased proportionally and theCH $\mathrm{H}_{4}$ increased slowly. With the increase in oxygen ions that were transported to the anode, more oxygen ions became involved in the formation of $\mathrm{H}_{2} \mathrm{O}$ and $\mathrm{CO}_{2}$. The methane that originally produced $\mathrm{CO}$ can also be more involved in the reaction of the formation of $\mathrm{CO}_{2}$ and $\mathrm{H}_{2} \mathrm{O}$, which made methane oxidation more thoroughly completed. The macroscopic experimental phenomena were that the methane of exhaust gas changed slowly with the increase of the current density.

\subsection{Reasons for the Voltage Drop}

Standard electric potentials for methane under complete oxidation, $\mathrm{CH}_{4}+\mathrm{O}_{2} \rightarrow \mathrm{CO}+\mathrm{H}_{2}+\mathrm{H}_{2} \mathrm{O}$ and methane partial oxidation at $1273 \mathrm{~K}$ were $1.067 \mathrm{~V}, 1.204 \mathrm{~V}$ and $1.444 \mathrm{~V}$, respectively [19]. Utilizing the Nernst equation of cell reactions to obtain the reaction of $\mathrm{CH}_{4}+3 / 2 \mathrm{O}_{2} \rightarrow \mathrm{CO}+2 \mathrm{H}_{2} \mathrm{O}$ at $1273 \mathrm{~K}$, its standard electric potential was $1.207 \mathrm{~V}$. The reaction led to a continuous decline in the potential voltage of the cell throughout the power generation process. The reason for the decline was polarization and the anode occurs through a series of reactions: $\mathrm{CH}_{4}+1 / 2 \mathrm{O}_{2} \rightarrow \mathrm{CO}+\mathrm{H}_{2}, \mathrm{CH}_{4}+\mathrm{O}_{2} \rightarrow \mathrm{CO}+\mathrm{H}_{2}+\mathrm{H}_{2} \mathrm{O}$ and $\mathrm{CH}_{4}+3 / 2 \mathrm{O}^{2-} \rightarrow \mathrm{CO}+2 \mathrm{H}_{2} \mathrm{O}$. With the increase in the number of oxygen negative ions in the reaction, the open circuit voltages of this series of reactions were continuously reduced. The cell generates power under a current density, but the anode reaction can change abruptly when the current density is suddenly altered. These changes resulted in cell output voltage abruptly dropping. The performance changes were associated with the anode reaction in the methane concentration of $3.85 \%$ of the cell when current density was more than $0.192 \mathrm{~A} \cdot \mathrm{cm}^{-2}$ (Figure 1 ).

Another reason for a drop in the cell voltage is when it produces $\mathrm{H}_{2} \mathrm{O}$, as in Figure 3. Gang Chen [9] [10] researched degradation causes of $\mathrm{Ni}$ based anode electrode via repeated tests under higher current and analyzed anode material with XRD. Researches showed that with the constant consumption of methane in particular, the reaction produced $\mathrm{H}_{2} \mathrm{O}$, and the $p\left(\mathrm{H}_{2} \mathrm{O}\right) / p\left(\mathrm{CH}_{4}\right)$ increased. This resulted in an active $\mathrm{Ni}$ of $\mathrm{Ni}$ based anode forming nickel hydroxide. Nickel hydroxide made the effective three-phase interface of anode reduction and decreased the cell performance.

In addition, when the reaction changed from consuming less oxygen negative ions to consuming more oxygen negative ions, oxygen negative ions cannot be timely supplied due to the interface resistance at cathode and anode. So the concentration polarization of oxygen negative ions were greatly induced. A double electric layer was formed near the three-phase interface. When the reaction that requires more oxygen ions occurred, the oxygen negative ions of the three-phase interface weren't able to replenish at the same rate. The proportion of the fixed layer potential difference of the double electric layer increased in the whole potential difference, which led to the output voltage of the cell decreasing, as the reaction of the cell required more oxygen ions in its potential. In order to maintain the same reaction under the same current density, the concentration polarization changed from the proportion of fixed layer potential difference of double electric layer dominating in the whole potential difference to a fixed layer and the dispersive layer took effect simultaneously. As a result, the cell output potential decreased continuously under the fixed current density.

Here, the activation polarization associated with different methane reactions occurred should be considered. Activation polarization is related to the activation energy. Based on the analysis of the reaction activation energy (Figure 5), the activation energy of producing $\mathrm{CO}_{2}$ was relatively high and subsequent reactions needed more oxygen ions. What's more, the exchange current density is the critical factor for the activation polarization [20].

$$
\text { the total activation loss }=A_{a} \operatorname{In}\left(\frac{i}{i_{0 a}}\right)+A_{c} \operatorname{In}\left(\frac{i}{i_{0 c}}\right)
$$

$i$ is the external current density, $i_{0 a}$ is anode exchange current density, $i_{o c}$ is cathode exchange current density, $A_{a}$ and $A_{c}$ are anode activation rate and cathode activation rate. 


$$
A_{a} \text { and } A_{c}=\frac{R T}{\alpha N F}
$$

$R$ is gas constant, $T$ is operating temperature, $a$ is electric charge transfer coefficient, $n$ is electron transfer number, and $F$ is faraday constant. The exchange current is inversely proportional to the activation polarization. The exchange current density declined when the reactants concentration were cut down. The reactants contained oxygen negative ions which cannot be provided in time. When oxygen negative ions concentration was decreased, the reactants concentration was also decreased. Therefore, the exchange current density decreased that could induce the activation polarization. Hence, there may be higher potential difference for activation polarization.

\section{Conclusion}

These experiments were conducted in order to test power generation performance of the cell on a Ni-ScSZ anode with different concentrations of dry methane as fuel. By combining the measurements of the anode exhaust gas and through examination of the activation energy on the cell anode oxidation reaction, the results were analyzed for the anode oxidation reaction in power generation process. Results showed that high concentrations of dry methane occurred following partial oxidation reactions on the cell anode. As the current density increased, there was a transition process from partial oxidation reaction to a complete oxidation reaction for low concentrations of dry methane. Although the partial oxidation reaction occurred with high concentrations of dry methane as fuel, good performance was able to be obtained. For low concentrations of dry methane, however, even if dry methane can occur following a complete oxidation reaction, $\mathrm{H}_{2} \mathrm{O}$ was produced in transition of reaction and resultant of reaction. The $\mathrm{H}_{2} \mathrm{O}$ resulted in the increase of $p\left(\mathrm{H}_{2} \mathrm{O}\right) / p\left(\mathrm{CH}_{4}\right)$. The polarization led to lower performance in a transition process of reaction.

\section{References}

[1] Kendall, K., Finnerty, C.M., Saunders, G. and Chung, J.T. (2002) Effects of Dilution on Methane Entering an SOFC Anode. Journal of Power Sources, 106, 323-327. http://dx.doi.org/10.1016/S0378-7753(01)01066-7

[2] Abudula, A., Ihara, M., Komiyama, H. and Yamada, K. (1996) Oxidation Mechanism and Effective Anode Thickness of SOFC for Dry Methane Fuel. Solid State Ionics, 86-88, 1203-1209. http://dx.doi.org/10.1016/0167-2738(96)00288-3

[3] You, H.X., Abuliti, A., Ding, X.W. and Zhou, Y.H. (2007) Reactions of Low and Middle Concentration Dry Methane over Ni/YSZ Anode of Solid Oxide Fuel Cell. Journal of Power Sources, 165, 722-727. http://dx.doi.org/10.1016/j.jpowsour.2006.12.041

[4] Yamamoto, O., Arati, Y., Takeda, Y., et al. (1995) Electrical Conductivity of Stabilized Zirconia with Ytterbia and Scandia. Solid State Ionics, 79, 137-142. http://dx.doi.org/10.1016/0167-2738(95)00044-7

[5] Ke, K., Gunji, A., Mori, H., et al. (2006) Effect of Oxide on Carbon Deposition Behavior of $\mathrm{CH}_{4}$ Fuel on Ni/ScSZ Cermet Anode in High Temperature SOFCs. Solid State Ionics, 177, 541-547. http://dx.doi.org/10.1016/j.ssi.2005.12.009

[6] Gunji, A., Wen, C., Otomo, J., et al. (2004) Carbon Deposition Behaviour on Ni-ScSZ Anodes for Internal Reforming Solid Oxide Fuel Cells. Journal of Power Sources, 131, 285-288. http://dx.doi.org/10.1016/j.jpowsour.2003.11.086

[7] You, H.X., Gao, H.J., Chen, G., Abudula, A. and Ding, X.W. (2011) The Conversion among Reactions at Ni-Based Anodes in Solid Oxide Fuel Cells with Low Concentrations of Dry Methane. Journal of Power Sources, 196, 27792784. http://dx.doi.org/10.1016/j.jpowsour.2010.09.082

[8] Perry Murray, E., Tsai, T. and Barnett. S.A. (1999) A Direct-Methane Fuel Cell with a Ceria-Based Anode. Nature, 400, 649-651. http://dx.doi.org/10.1038/23220

[9] Liu, J. and Barnett, S.A. (2003) Operation of Anode-Supported Solid Oxide Fuel Cells on Methane and Natural Gas. Solid State Ionics, 158, 11-16. http://dx.doi.org/10.1016/S0167-2738(02)00769-5

[10] Sfeir, J., Buffat, P.A., Möckli, P., et al. (2001) Lanthanum Chromite Based Catalysts for Oxidation of Methane Directly on SOFC Anodes. Journal of Catalysis, 202, 229-244. http://dx.doi.org/10.1006/jcat.2001.3286

[11] Zhan, Z.L., Lin, Y.B., Pillai, M., Kim, I. and Barnett, S.A. (2006) High-Rate Electrochemical Partial Oxidation of Methane in Solid Oxide Fuel Cells. Journal of Power Sources, 161, 460-465. http://dx.doi.org/10.1016/j.jpowsour.2006.04.139

[12] You, H.X., Gao, H.J., Chen, G., Abudula, A. and Ding, X.W. (2011) The Conversion among Reactions at Ni-Based 
Anodes in Solid Oxide Fuel Cells with Low Concentrations of Dry Methane. Journal of Power Sources, 196, 27792784.

[13] Chen, G. (2011) Fabrication of Cathod-Supported SOFC with High Performance and Degration Mechanism of Ni-Base Anodes at High Current Density. Hirosaki University, Hirosaki City.

[14] Chen, G., Guan, G.Q., Kasai, Y., You, H.X. and Abudula, A. (2011) Degradation Mechanism of Ni-Based Anode in Low Concentrations of Dry Methane. Journal of Power Sources, 196, 6022-6028.

[15] Qi Bo (2009) The Intrinsic Kinetics of Methane Steam Reforming and Reaction Performance Study in Micro-Channel Reactor. Chongqing University, Chongqing.

[16] Hecht, E.S., Gupta, G.K., Zhu, H.Y., Dean, A.M., Kee, R.J., Maier, L. and Deutschmann, O. (2005) Methane Reforming Kinetics within a Ni-YSZ SOFC Anode Support. Applied Catalysis A: General, 295, 40-51. http://dx.doi.org/10.1016/j.apcata.2005.08.003

[17] Zhu, H.Y., Kee, R.J., Janardhanan, V.M., Deutschmann, O. and Goodwin, D.G. (2005) Modeling Elementary Heterogeneous Chemistry and Electrochemistry in Solid-Oxide Fuel Cells. Journal of the Electrochemical Society, 152, A2427-A2440. http://dx.doi.org/10.1149/1.2116607

[18] Wu, T.H. and Wang, H.Y. (1996) A Study on the Bond-Order-Conservation Model of the Mechanism of Methane Partial Oxidation to Syngas on Ni. Journal of Zhejiang Normal University (Natural Sciences), 19, 48-52.

[19] Zhang, X.G., Ohara, S., Chen, H. and Fukui, T. (2002) Conversion of Methane to Syngas in a Solid Oxide Fuel Cell with Ni-SDC Anode and LSGM Electrolyte. Fuel, 81, 989-996. http://dx.doi.org/10.1016/S0016-2361(02)00012-1

[20] Gang, X. (2009) Fuel Cell Technology. Publishing House of Electronics Industry, Beijing. 
Scientific Research Publishing (SCIRP) is one of the largest Open Access journal publishers. It is currently publishing more than 200 open access, online, peer-reviewed journals covering a wide range of academic disciplines. SCIRP serves the worldwide academic communities and contributes to the progress and application of science with its publication.

Other selected journals from SCIRP are listed as below. Submit your manuscript to us via either submit@scirp.org or Online Submission Portal.
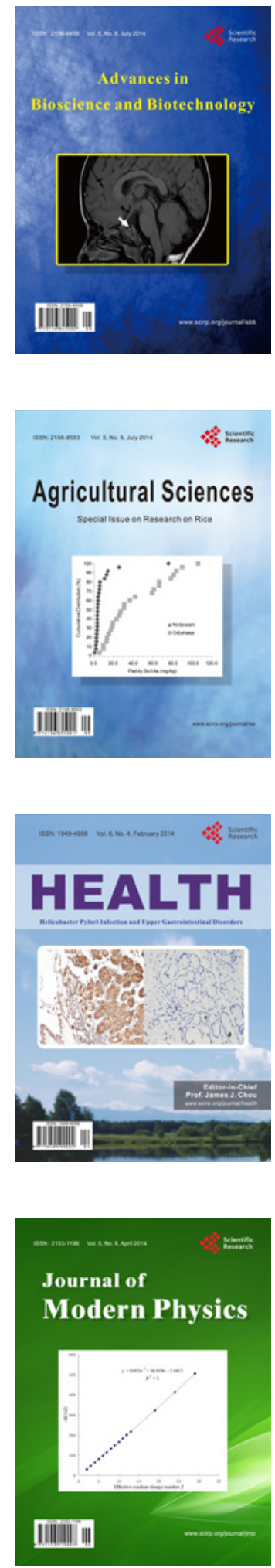
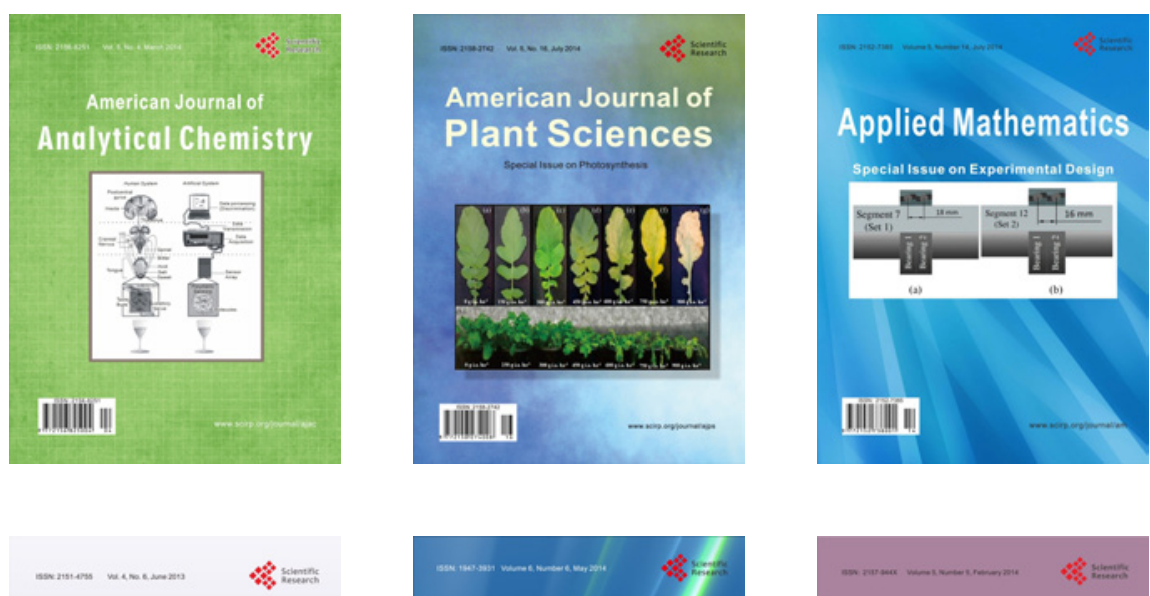

Creative Education
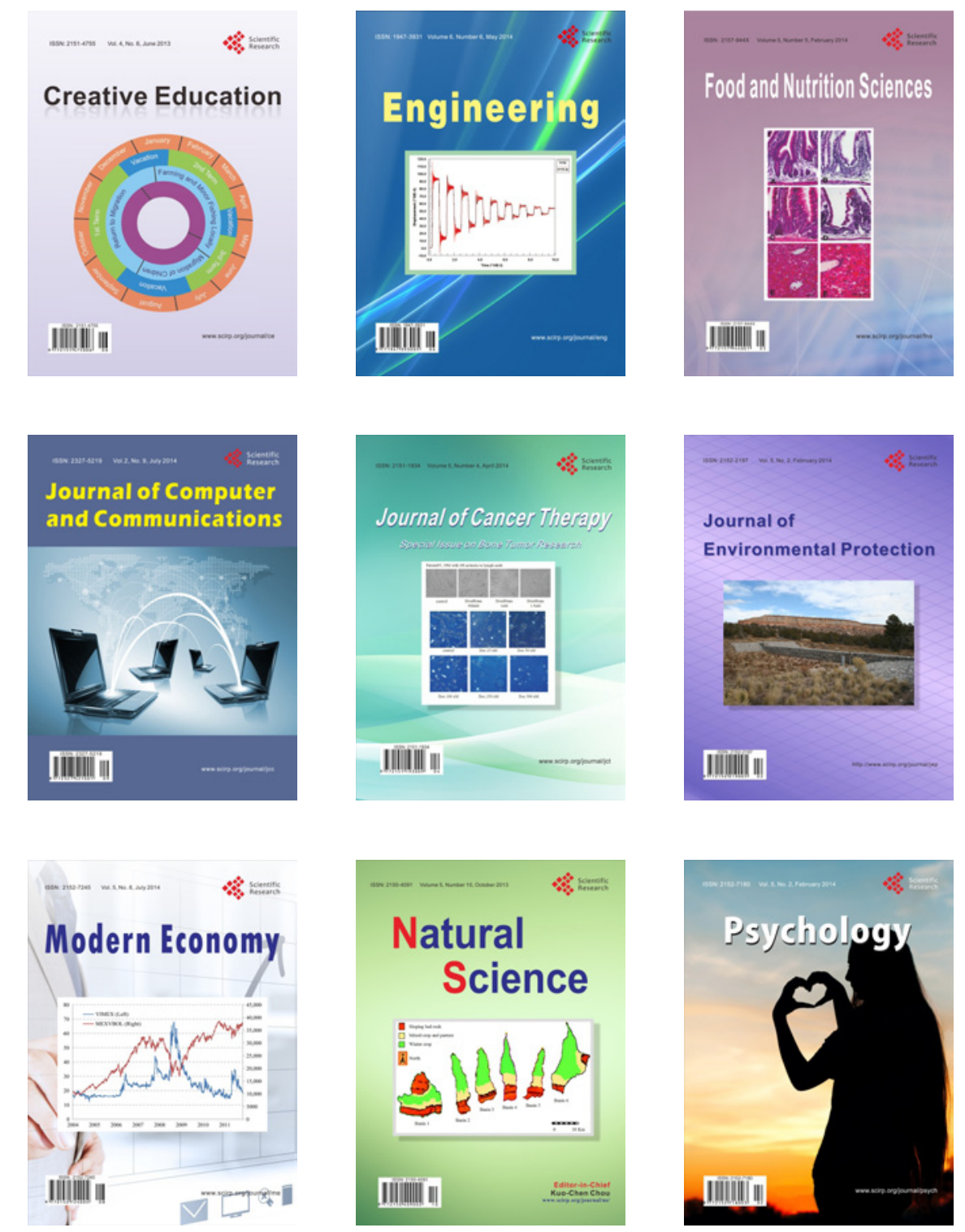